\title{
Cloud Computing for Universities: A Prototype Suggestion and use of Cloud Computing in Academic Institutions
}

\author{
Sarvesh Kumar \\ Computer Science \& Engineering \\ LPU, India
}

\author{
Omkara Murthy \\ Asst.Professor,CSE \\ LPU,India
}

\begin{abstract}
Now a day's cloud computing became an attractive area of research and practices over the last few years. An increased number of private and public sector organizations have either adopted cloud company based solutions or seriously consider moving to cloud computing. In this paper we initiated a project designing and setting up a private cloud infrastructure in an academic environment. The objective of this research paper is find alternatives to the use of IT, while leading universities to improve power consumption, energy and obtain cost savings. Public cloud computing has potential to reduce information and communication technology costs by virtualized capital assets such as disk storage but in case of private cloud, university should consider private cloud deployment models to realize scale on demand, rapid platform deployment. Use of cloud computing an university has many benefits such as research projects, files, databases and tools for faculty, staffs and students in the university. It reduces university IT complexity and cost. Researcher runs simulations through message passing interfaces to solve complex problems by no. of virtual machines but we will show a private cloud development for university to support such requirements. The article begins with introduction to cloud computing in universities in first section. In the second section we discuss on characteristic and deployments of cloud computing. Then we discuss the implementation of cloud computing at universities and at last we will see suggested prototype architecture of university campus.
\end{abstract}

\section{INTRODUCTION}

Higher education is one of the pillars of society development. The partnership between universities, industries and governments and students have proved contribution to society and transferred the entire economy of the world (lozowsk et al 2008). The major factor in promoting cloud computing has been recognition that large data centers have thousand of servers that generally do not operate on full capacity. By using these resources more efficiently through virtualization. Cloud computing enables greater returns on data center investments and it makes it possible for a university to create its private cloud within its infrastructure. Small business and academics in university are not aware of benefits and characteristics and cost of cloud computing. Google has designed Google Apps. For educational usage and IBM launched IBM cloud academy that provides a forum for researchers, IT professionals and educators. According( Golden,2010) at this newest universities are confronting within dramatic increase of costs in higher education more than inflation rate and decrease of finding some alternatives means of reaching their purpose. Within present economical context, the use of cloud computing be necessary not a option for many universities. These aspects due to many factors such as cost increase the pressure of income increase student success and institution performance. IT industry, coupled with the significant benefits that cloud computing promises to deliver to believe that cloud computing will be widely used in higher education, at time they understands the features of higher education IT requires a careful evaluation how and when adopt cloud computing and makes it possible to create our own create a private cloud for Academic institution. In this paper we will show prototype cloud architecture for university and implementation of private cloud computing approach.

\section{Problems for cloud computing in universities:}

- During off seasons of academics and universities, it's totally wastage of hardware, power management and cooling resources and implementation enable universities to build a solution once and then use that solution many times. This lower costs, increase reliability and reduces times to implementation.

- Cost/benefits ratio achieved depend on many unique factors and will vary significantly.

- $\quad$ Security of data which is used by students and faculties in research development.

Challenges for building a private cloud for university purpose:

- Build a private cloud environment to refurbish the university information siles.

- Achieved improved system while reducing the costs required revamping the existing systems.

- Reduce the complexity of student ID management for university students.

\section{Solution of these challenges:}

University built its own internal cloud running on blade servers and virtualization software. This has enabled university to provide enhanced services for all students and graduates. This new cloud computing environment will be constructed inside the third party data centre which is equipped with highest levels of security and disaster resiliency. With the implementation of ID management System University can assign a totally unique life ID to each individual student. This improves management efficiency, enabling university to provide better student services and enhanced career support is perfect to each students needs. 


\section{Demands in complex environment for university:}

1. University are facing a lot of challenges to their management of students, classes and faculties where lots of collaboration between them.

2. Deploying applications and web based student services at rapidly accelerating rate without increase the budget of software and hardware.

3. Reducing the capital expenditure and operational expenditure while maintaining the highest level of security and privacy.

4. Competing among other universities, many of which attempt to differentiate themselves in the market based on the services that they offer to students.

5. Security is a special issue for institutions of higher education where students and faculty are pursuing research. A secure and reliable networking infrastructure is therefore the flat out requester.

Private cloud based systems appeared to the best option to meet university objectives

Goals for developing private cloud for university:

1. To deliver high quality, consistent services.

2. To ensure a stable systems for students.

3. To reduce associated costs.

High levels of new and upgraded services in university

- Improvements in library management System University can manage all the books in its libraries easier and more efficiently than ever.

- University to provide student, graduates, faculty and even local communication members with access to a database offering wide variety of academic resource.

Approaches and steps for creating a private cloud for universities:

private cloud basically, it is cloud infrastructure setup, managed and upgraded by an organization or community for their own use. e.g. eucalyptus, openNebula, openStack

\section{steps for creating a private cloud:}

a. Adapt machine virtualization strategy

b. Profile application compute, memory and storage usage and performance requirements.

c. Design a virtual machine consultancy.

d. Accounting and recharge policies adapted to self services.

e. Architect a deployment and deploy a private cloud.

why private cloud for university:

1. The need of processing large data volumes.

2. The need to conserve power by optimizing server utilization.
3. Analyzing large amounts of data or set results.

4. Many different research projects in the organization.

5. Having higher rate of infrastructure than traditional infrastructure

6.More customizable

7.Can quick respond to changes in demands.

8.Have increased security.

9. Focus on organization core business.

CPU and Memory for private cloud deployments:

1.processor architecture: Intel \& AMD, Definitely 64bit for performance reasons, multi processor, multi core and hyper threading.

2. virtual extension hardware: Intel VT-X, virtualization enabled hardware.

3. hosts RAM minimum 4 GB.

4. enable KSM(kernel same page memory)

characteristics, barriers and limitations of private cloud for higher education

characteristics of private cloud:

pooled resources: in the private cloud compute, storage and networking are pooled and abstracted into units that enabled for dynamic provision.

self-service: deliver applications and resources a services. it is also responsible for automated provisioning.

elastic: IT services can be scaled up or down almost instantly to meet business requirements.

usage based: it is based on resources as services, users can metered customers pay for only the resources that are actually consumed.

Barriers to Adoption:

\begin{tabular}{|l|l|}
\hline Security & $\begin{array}{l}\text { Privacy: users do not } \\
\text { have control where } \\
\text { their data is being } \\
\text { stored }\end{array}$ \\
\hline Control & $\begin{array}{l}\text { The amount of control } \\
\text { that the user has over } \\
\text { the cloud environment }\end{array}$ \\
\hline interoperability & $\begin{array}{l}\text { Universal set of } \\
\text { standards }\end{array}$ \\
\hline reliability & $\begin{array}{l}\text { Many existing cloud } \\
\text { infrastructure leverage } \\
\text { commodity hardware } \\
\text { that is known to fail }\end{array}$ \\
\hline performance & $\begin{array}{l}\text { All access to the cloud } \\
\text { is done via the internet }\end{array}$ \\
\hline
\end{tabular}


Benefits and Limitations of cloud computing for higher education:

\begin{tabular}{|l|l|}
\hline $\begin{array}{l}\text { Access to applications } \\
\text { from anywhere }\end{array}$ & $\begin{array}{l}\text { Not all applications run } \\
\text { in the cloud }\end{array}$ \\
\hline $\begin{array}{l}\text { Increased openness of } \\
\text { students to new } \\
\text { technologies }\end{array}$ & $\begin{array}{l}\text { Security and protection } \\
\text { of data }\end{array}$ \\
\hline $\begin{array}{l}\text { Support for teaching } \\
\text { and learning }\end{array}$ & Organizational support \\
\hline $\begin{array}{l}24 \text { hour access to } \\
\text { infrastructure and } \\
\text { content functional }\end{array}$ & Lack of confidence \\
\hline $\begin{array}{l}\text { Increased fual property } \\
\text { capabilities }\end{array}$ & \\
\hline
\end{tabular}

\section{Cloud computing for universities:}

private clouds for universities are internal to organization and hence it provides security, better control on usage cost and pricing model. private clouds are not used for large organization but it also now used for universities which have few services. An Universitylike Lovely Professional University, India can benefit significantly from private cloud infrastructure to services its IT, research and teaching requirements. in this paper we showed with selecting a private cloud infrastructure which has 45000 students, 2000 faculties and more than 2000 work stations and around 50 server grade machines to manage our IT infrastructure. LPU has many different labs and server rooms scattered across the campus. our aim to consolidate this infrastructure by setting up a private cloud and provides VM to run their workloads. this can reduce hardware, power and management costs.

\begin{tabular}{|l|l|l|l|l|l|}
\hline Name & Owner & Host & RAM & Port & State \\
Demovm1 & 11108930 & 102.2 .71 .4 & 512 & 2532 & Running \\
Demovm2 & 11100454 & 102.2 .71 .4 & 512 & 2533 & Paused \\
Demovm3 & 11104690 & 102.2 .71 .4 & 512 & 2534 & off \\
\hline
\end{tabular}

list of virtual machines in private cloud data bases.

\section{a. deconstructing private cloud model:}

web server: it provides a web based interface for management of the virtual machine

b. Hosts: multiple hosts are configured and registered in the private cloud data base using web server interface. c. client: any client can access the virtual machine.

\section{d. server test:}

\begin{tabular}{|l|l|l|l|}
\hline Test & RAM & Hypervisor & VMware \\
Fork(732.59 MB) & $305 \mathrm{~s}$ & $4.22 \mathrm{~s}$ & $1.42 \mathrm{~s}$ \\
OSCP(629 MB) & $45 \mathrm{~s}$ & $6.21 \mathrm{~s}$ & $3.25 \mathrm{~s}$ \\
OSCA(640 MB) & $53 \mathrm{~s}$ & $9.32 \mathrm{~s}$ & $6.20 \mathrm{~s}$ \\
\hline
\end{tabular}

Difference between public and private cloud computing:

\begin{tabular}{|l|l|l|}
\hline Model & Public & Private \\
\hline $\begin{array}{l}\text { Owned and } \\
\text { managed by }\end{array}$ & $\begin{array}{l}\text { Service } \\
\text { provider }\end{array}$ & university \\
\hline access & $\begin{array}{l}\text { By } \\
\text { subscription }\end{array}$ & $\begin{array}{l}\text { Limited } \\
\text { students, } \\
\text { staff of } \\
\text { university }\end{array}$ \\
\hline $\begin{array}{l}\text { Customization } \\
\text { and control }\end{array}$ & none & yes \\
\hline
\end{tabular}



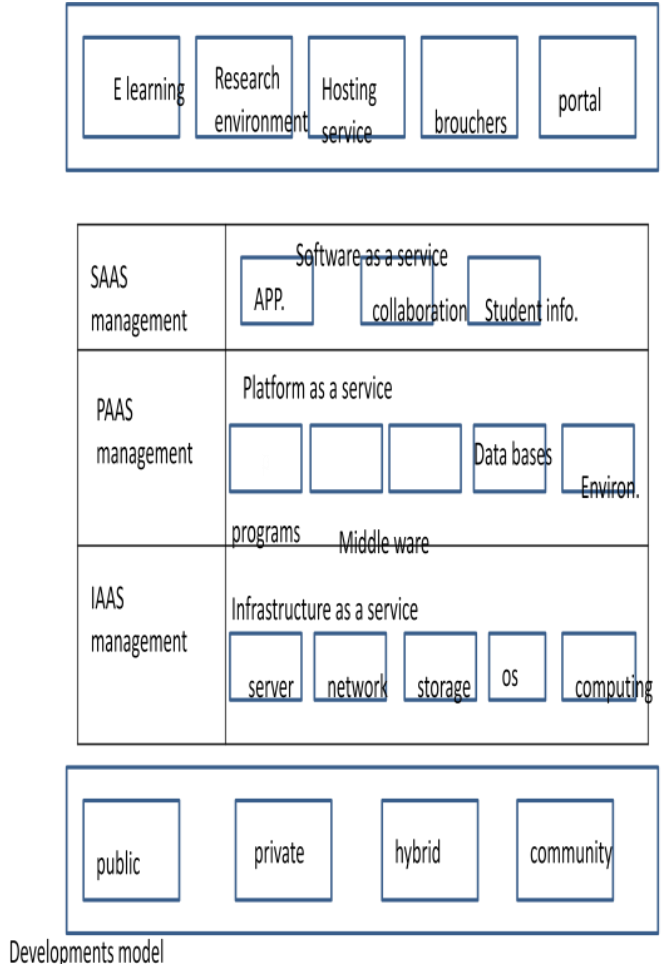

Developments model

Fig.1 cloud computing for university

the cloud model appeared due to the increase of pressure in the educational environment. the next process describes the method in which student may access and modify their information in the cloud (figure 1).

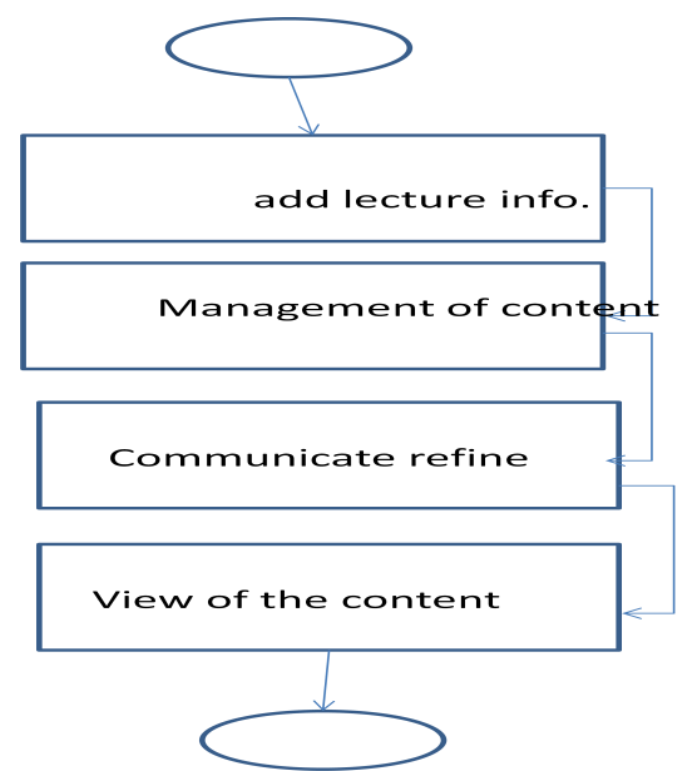

fig 2 . students add information in the cloud.
Implementation result for private cloud for university purposes:

1. Based on cost structure: costs are varies with its type( class). in the previous work which is done by WIKIBON are as follows:

class 1- development, small scale app., database servers.

class 2- small data warehousing, medium small scale up, data marts.

class 3- large scale DB servers, large scale messaging

class 4- large scale app. running highest level of security.

following diagram will show a cost comparison of class 3 application of an organization with greater than $\$ 1$ in revenue of budget.

Table: cost breakdown structure between private cloud and public cloud in university

private cloud public cloud

\begin{tabular}{|l|l|l|}
\hline $\begin{array}{l}\text { Departmental staff } \\
\text { cost }\end{array}$ & $\$ 350$ & $\$ 350$ \\
\hline $\begin{array}{l}\text { Operational staff } \\
\text { cost }\end{array}$ & $\$ 90$ & $\$ 80$ \\
\hline Outsourcing costs & $\$ 25$ & $\$ 700$ \\
\hline $\begin{array}{l}\text { Infrastructure } \\
\text { software }\end{array}$ & $\$ 100$ & $\$ 10$ \\
\hline App. software costs & $\$ 134$ & $\$ 134$ \\
\hline $\begin{array}{l}\text { Network } \\
\text { infrastructure cost }\end{array}$ & $\$ 50$ & $\$ 110$ \\
\hline $\begin{array}{l}\text { Storage } \\
\text { infrastructure }\end{array}$ & $\$ 50$ & $\$ 10$ \\
\hline $\begin{array}{l}\text { Server } \\
\text { infrastructure }\end{array}$ & $\$ 115$ & $\$ 15$ \\
\hline Total & $\$ 914$ & $\$ 1409$ \\
\hline
\end{tabular}




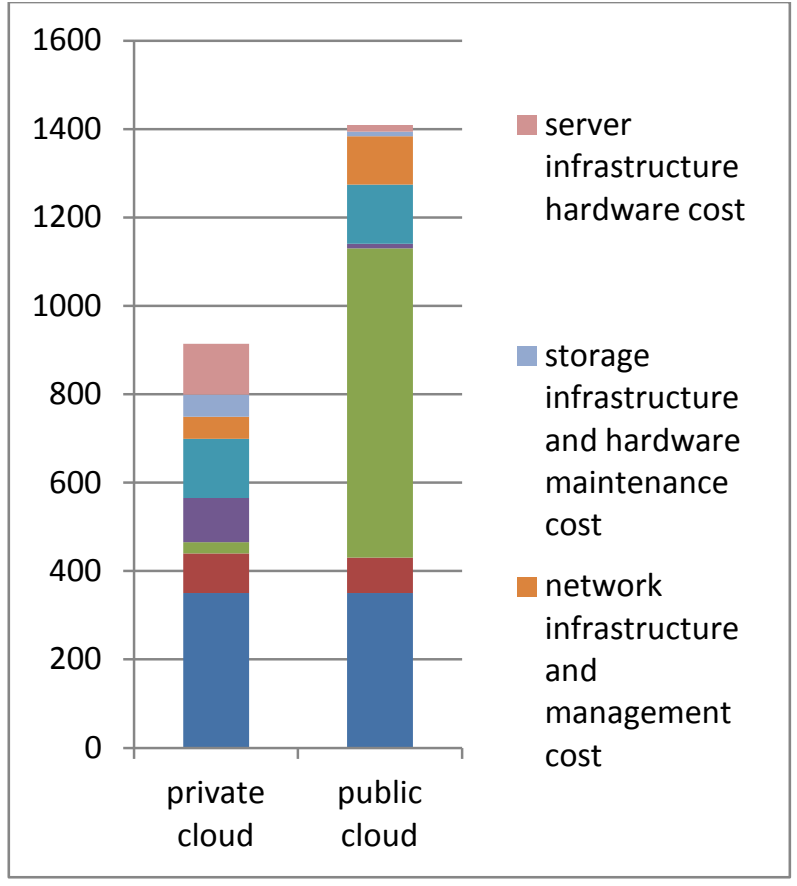

\section{fig. 3 shows that adoption for cloud computing in university}

\section{Results of private cloud approach for university}

We derived a new propose approach for creation of private cloud for academic purposes. The result of implementing a private cloud will proof that universities can reduce their power, energy and space constraints and can manage their records of students for a long time in their cloud. Universities can also use other benefits like educational system, research tools for faculty and students based on demand. Universities can also reduce their expenditure cost by decreasing their demand for licensed software.

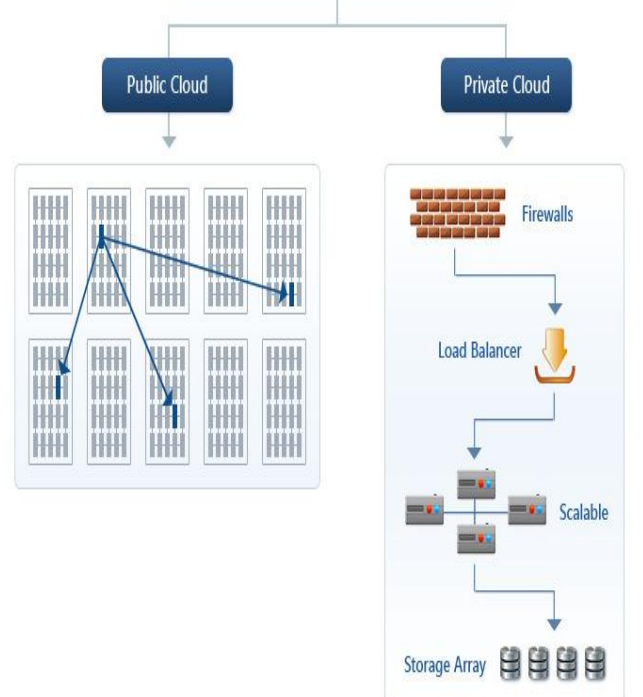

Figure 4: It describes the main Conclusion that which cloud computing is suitable for the organization according to the need.

\section{Cost comparison over 3 years:}

This comparison is based upon assumption of course.

There are various factors that would go into implementation for discussion purposes. For the purposes of cloud computing for university assumptions are following:

\section{For public cloud:}

- Assumed all instances of public or private cloud server usage can be active $24 * 7$.

- For calculate public cloud using 20 extra large CPU classes, 30 small CPU classes and 60 large CPU classes.

- For initial purpose we take a scenario of 250 virtual server systems.

\section{For private cloud:}

- Included a silver level support

- Included all needed servers, storages, switching and software infrastructure which comes on private cloud scenario.

- It also includes cost for racks, power and space

at a co-located data center facility in the private cloud scenario.

Public cloud:

\begin{tabular}{|c|c|c|c|c|}
\hline & $\begin{array}{c}\text { Year1 } \\
\$\end{array}$ & $\begin{array}{c}\text { Year2 } \\
\$\end{array}$ & $\begin{array}{c}\text { Year3 } \\
\$\end{array}$ & $\begin{array}{c}\text { Commulative } \\
\$\end{array}$ \\
\hline $\begin{array}{c}\text { Capital } \\
\text { Expense }\end{array}$ & $\$-$ & $\$-$ & $\$-$ & $\$-$ \\
\hline $\begin{array}{c}\text { Operating } \\
\text { expense }\end{array}$ & 314625 & 361800 & 413974.51 & 1090399.51 \\
\hline total & 314625 & 361800 & 413974.51 & 1090399.51 \\
\hline
\end{tabular}

Private cloud Purchase:

\begin{tabular}{|c|c|c|c|c|}
\hline & $\begin{array}{c}\text { Year1 } \\
\$\end{array}$ & $\begin{array}{c}\text { Year2 } \\
\$\end{array}$ & $\begin{array}{c}\text { Year3 } \\
\$\end{array}$ & $\begin{array}{c}\text { Commulative } \\
\$\end{array}$ \\
\hline $\begin{array}{c}\text { Capital } \\
\text { Expense }\end{array}$ & 315500 & 315500 & 315500 & 946500 \\
\hline $\begin{array}{c}\text { Operating } \\
\text { expense }\end{array}$ & 90950 & 85342 & 88342 & 261634 \\
\hline total & 406450 & 400842 & 400842 & 577134 \\
\hline
\end{tabular}

Private cloud lease:

\begin{tabular}{c|c|c|c|c|}
\hline & $\begin{array}{c}\text { Year1 } \\
\$\end{array}$ & $\begin{array}{c}\text { Year2 } \\
\$\end{array}$ & $\begin{array}{c}\text { Year3 } \\
\$\end{array}$ & $\begin{array}{c}\text { Commulative } \\
\$\end{array}$ \\
\hline $\begin{array}{c}\text { Capital } \\
\text { Expense }\end{array}$ & $\$-$ & $\$-$ & $\$-$ & $\$-$ \\
\hline $\begin{array}{c}\text { Operating } \\
\text { expense }\end{array}$ & 203900.80 & 198204.80 & 198204.80 & 600310.4 \\
\hline total & 203900.80 & 198204.80 & 198204.80 & 600310.4
\end{tabular}

\section{A prototype architecture for university purpose:}

in this section we suggested a architecture scenario to using a cloud computing for university purpose. every day research and educational needs of universities changes the technology. for example, some applications, programming language, and courses in computer education \& industrial development also needs. as a result, new software causes new hardware costs, students uses both the software and development platforms 
for developing applications. but there is an issue of setup, configure and management of new tools. cloud computing for university can manage all these issues. students will have access software, documents anytime, anywhere and any technology connected to internet by suggested cloud structure.

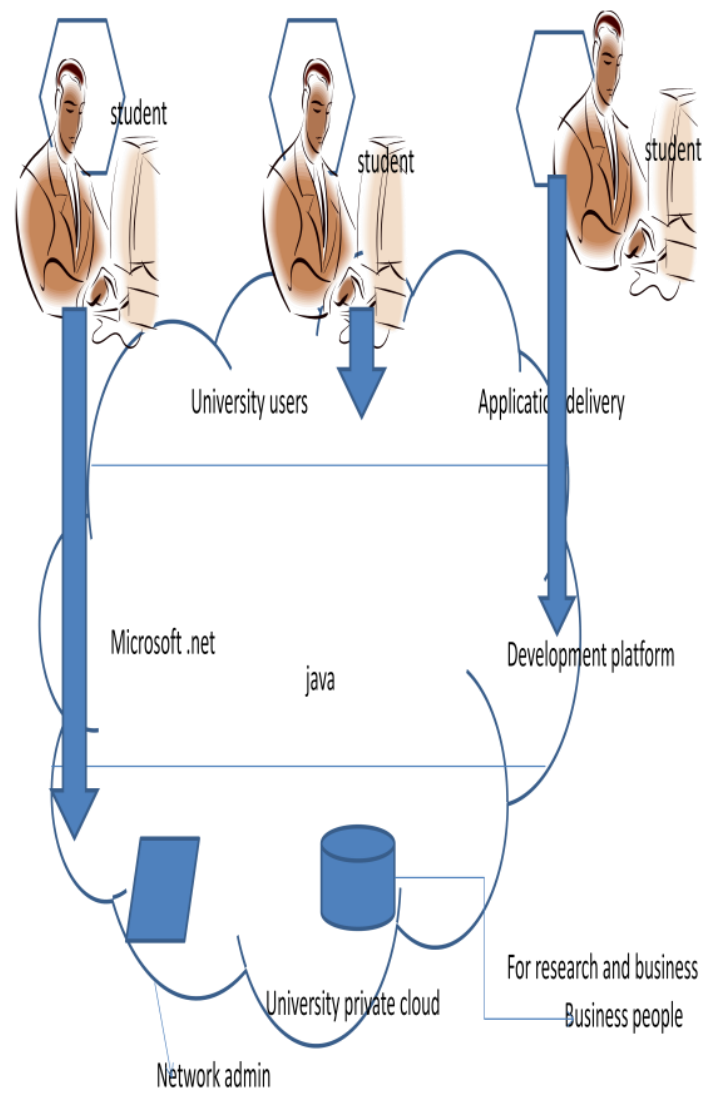

fig 5 A prototype architecture for university purpose

\section{Conclusion and future scenario}

university achieves rapid disaster recovery, stable system operates and significant energy savings. the private cloud deployment at university has already delivered many advantages to the university without having invest a large amount of money, we can now use powerful, industry leading features and functionality that enables us to be more responsive to the change needs of society. an advantage is that greatly improved resource optimization and efficiency gained through the use of shared infrastructure. at universities, work load fluctuates. throughout the year and now cloud environment will help stabilize services during the periods of fluctuation. During peak times of undergraduate registration a temporal surge in the work load experienced, now those have ability to add additional resources in order to process all registration property. Shifting to private cloud approach has enabled university not only to achieve improved system efficiency and stability but it also makes university ecofriendly place. university will be reduces to the no. of physical services by $60 \%$.

\section{Acknowledgements:}

First of all I would like to thank my parents for supporting me through all phases of my life, then I would like to thank my mentor for being a great motivator and helping me in all aspects, finally I will thank my friends Saurabh Srivastav,Vijay kumar,Prateek Singh,Vinay Srivastava and Neerja Patel to motivate me for writing the paper.

\section{REFERENCES:}

[1] Cisco (2010)," Cloud computing in higher education :A Guide to Evaluation and Adoption", [online] Available: http://www.cisco.com/web/offer/email/43468/5/cloud computing_in_Higher_Education.pdf

[2] Cloud Computing, [online] Available: http://en.wikipedia.org/wiki/cloud_computing

[3] Software Engineering Institute, Carnegie Mellon," System of Systems, Barriers to Adoption", [online] Available: http://www.sei.cmu.edu/sos/research/cloud computing/cloudbarriers.cfm

[4] Mell P.,Grance T.," The NIST Defination of cloud computing", [online] Available: http://csrc.nist.gov/publications/nistpubs/800-145/SP800145.pdf

[5] Cisco, "Data Center Solutions for Education", [online] Available:www.cisco.com/go/edudatacenter

[6] Moother,J.;Bhatt,V.(2009):A cloud computing solution for universities: virtual computing lab:case study of North Carolina state university,www.google search engine.

[7] Right Scale Inc.(2009):Right Scale cloud management features, http://www.rightscale.com/products/features

[8] Ibm.com/developer work (15 Dec 2009).

[9] Webhosting, U.(2008): Cloud Computing service comparison guide, www.erbhostingurleashed.com

[10] Siegle,D.(2010). Cloud Computing: A Free Technology Option to Promote Collaborative Learning. Gifted Child Today,33(4),41-45

[11] Gurman,G,.\&Knorr,E.(2008,April 7). what cloud computing really means.Retrieved March 11,2011,from infoworld:http://www.infoworld.com/d/cloudcomputing/ what-cloud-computing-really-means-031

[12] Furht,B.,\&Escalante,A.(2010) Handbook of cloud computing. New York:Springer

[13] Kavis, M. (2009)." A Move to cloud computing should involve SOA and BPM," TechTarget,CIO News.[online], [retrieved October 5,2010]

[14] ISACA(2009)." cloud computing Business benefits, With Security, Governance and Assurance perspectives SearchSecurity.com,1-10 